\title{
Os isotope and PGE evidence for modification of cratonic lithosphere: A study of peridotites from the Premier mine, Kaapvaal Craton, SA
}

\author{
${ }^{1}$ M. Morel, ${ }^{1}$ G.R. Davies, ${ }^{2}$ D.G. Pearson, ${ }^{3}$ K.S. Viljoen, ${ }^{2}$ A. Luguet, ${ }^{2}$ N. Wittig \\ ${ }^{1}$ Faculty of Earth and Life Sciences, Vrije Universiteit, Amsterdam, The Netherlands, morel.melanie@falw.vu.nl \\ ${ }^{2}$ Arthur Holmes Isotope Geology Institute, Durham University,UK \\ ${ }^{3}$ MINTEK, fanusv@mintek.co.za
}

The Kaapvaal subcontinental lithospheric mantle (SCLM) is mainly Archaean in age (Pearson et al, 2003) and formed as residua from partial melting. It is characterised by depletion in basaltic melt components, but contains high silica and incompatible trace element contents indicative of a complex meltfluid enrichment history (Kelemen et al, 1998; Simon et al, 2007). Tomographic studies (Fig. 1) have established that Kaapvaal SCLM forms a thick buoyant lithospheric root except for a region where a marked seismic anomaly coincides with the region of a major magmatic activity that formed the Bushveld Province at 2.05Ga. This study of mantle xenoliths from the Premier kimberlite aims to establish the effect of this major magmatic event on the SCLM with a study of mantle xenoliths from the Premier kimberlite pipe that erupted through the centre of the seismic anomaly. The specific goal is to determine if new SCLM was formed at $2.05 \mathrm{Ga}$ or if there was a major modification of the existing SCLM.

\section{Geophysics}

The uppermost mantle beneath the Bushveld Province is characterised by low $\mathrm{P}+\mathrm{S}$ waves velocities compared to rest of the Kaapvaal Craton (Fig.1). Bushveld activity in the Proterozoic may have produced new depleted mantle or fertilised the existing SCLM. Both processes would produce relative iron enrichment and hence reduce seismic velocities relative to extensively melt depleted Archaean SCLM. From an examination of 110 xenoliths and previous studies (Danchin et al, 1979) the average composition and mineral modes of Premier xenoliths was calculated. Compared to average Kaapvaal composition (Pearson et al. 2003) this composition is $3 \%$ richer in clinopyroxene and $2 \%$ richer in garnet, which is sufficient to explain the $0.5 \%$ difference observed in present-day seismic velocities.

\section{Major and trace elements}

The Premier xenolith suite contains two peridotite populations (Fig. 2.). The first is typical of depleted low-T peridotites from the Kaapvaal Craton and has an average olivine of Mg\# 92.4, identical to that seen in the Kaapvaal crtaon and globally (Bernstein et al., 2006; Pearson \& Wittig, 2008). The second Premier peridotite group has a more fertile composition, with olivine $\mathrm{Mg} \#=90.6-91.3$ (Fig.2)

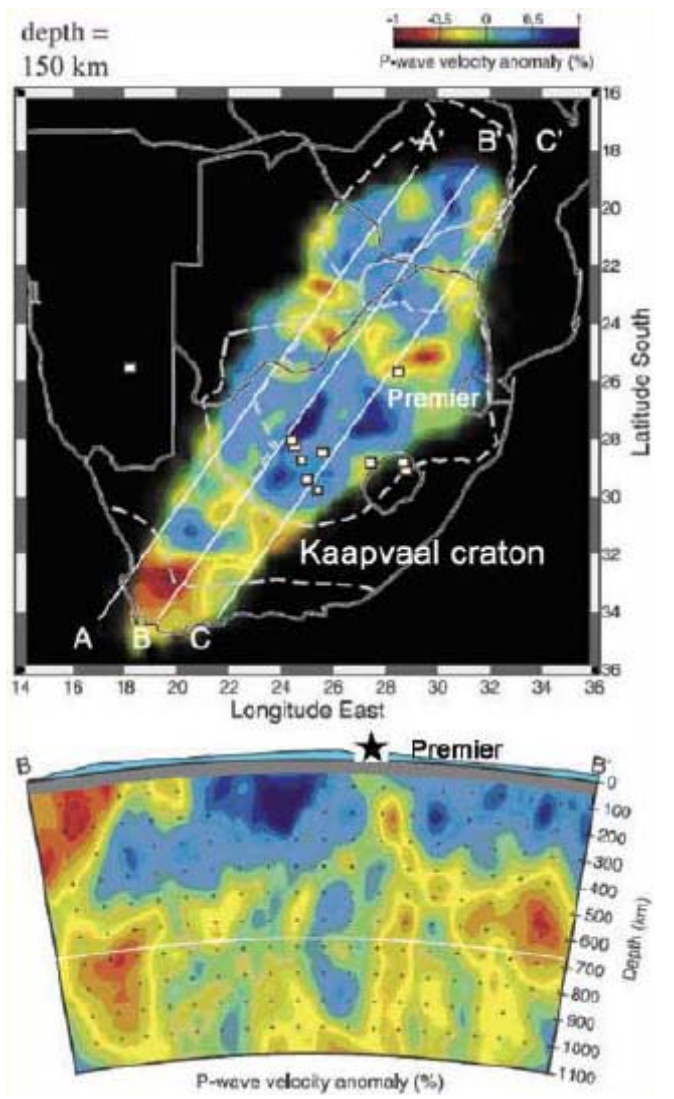

Fig.1 Map of velocities perturbations at $150 \mathrm{~km}$ depth and cross section along Kaapvaal Craton BB' profile (James et al., 2004).

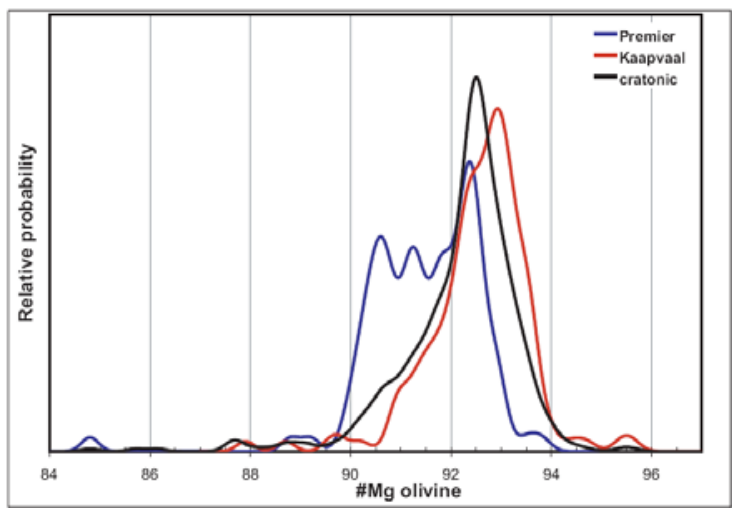

Fig.2 Probability distribution of \#Mg olivine for Premier and Kaapvaal craton (Pearson \& Wittig, 2008).

The amount of melt extraction from a peridotite can be estimated from the \#Mg of olivine (Bernstein et al., 2006). Based on this approach the two Premier 
peridotite suites experienced approximately 20 and $>30 \%$ melting respectively.

Major elements are not strong indicators of melting depth in metasomatised cratonic peridotites. Considering FeO-MgO systematics (Fig. 3a) scatter in FeO data is partly caused by orthopyroxene addition typical of Kaapvaal craton (Lee, 2006). The addition of opx lowers the bulk FeO without strongly affecting the $\mathrm{MgO}$ while olivine $\mathrm{Mg}$ numbers remain relatively unaffected because of the high $\mathrm{Mg}$ number of the added orthopyroxene. Premier samples spread towards higher pressure melting curves (Fig.3a). Mg-Al systematics (Fig. 3b) are less effect from opx, but cpx or garnet addition will lead to higher inferred melting pressures. Nonetheless, most sample record less than $30 \%$ melting at around 2 to 3GPa (Fig.3b).

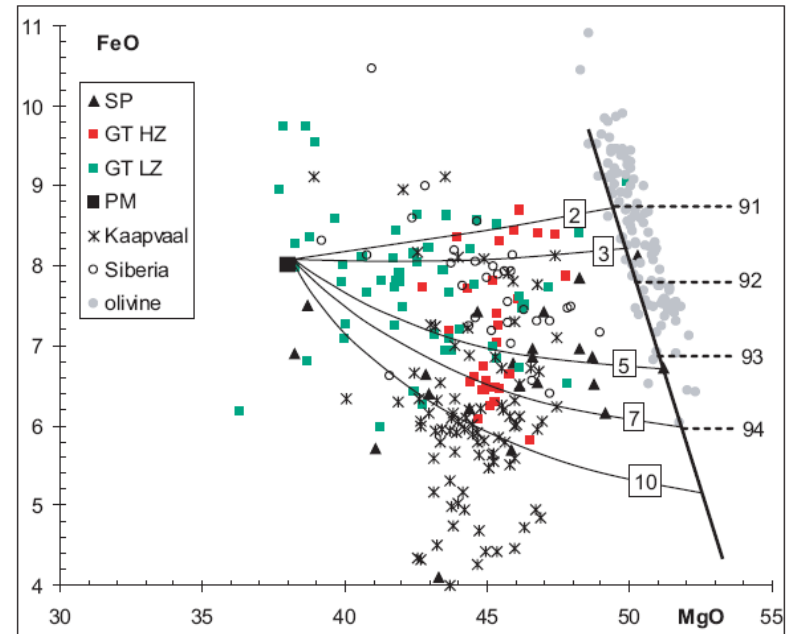

Fig.3 a \& b: Bulk rock in wt\% $\mathrm{MgO}$ versus $\mathrm{FeO}$ and $\mathrm{Al}_{2} \mathrm{O}_{3}$ for Premier peridotites. Solid black lines are the fractional melting trajectories for different pressures (2, 3, 5, 7, 10GPa) taken from Herzberg, 2004. In figure 3b, melt extraction equiline of $30 \%$ (larger extent of melting on ont the right of this line). Kaapvaal and Siberia whole rock analytical data sources are from the compilation of Pearson \& Wittig, 2008.

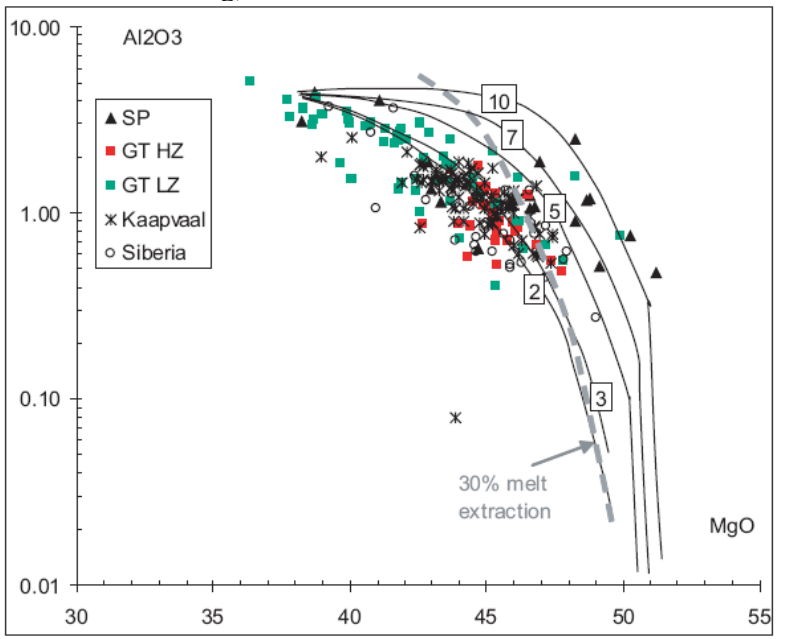

Moderately incompatible elements such as $\mathrm{Yb}$ or $\mathrm{Lu}$ are less sensitive to modal- and kimberlitemetasomatism.
These elements also record extensive degrees of melting at pressure mostly below 3GPa (Pearson \& Wittig, 2008, Fig. 4), consistent with peridotites from most of other cratons (Wittig et al., this volume).

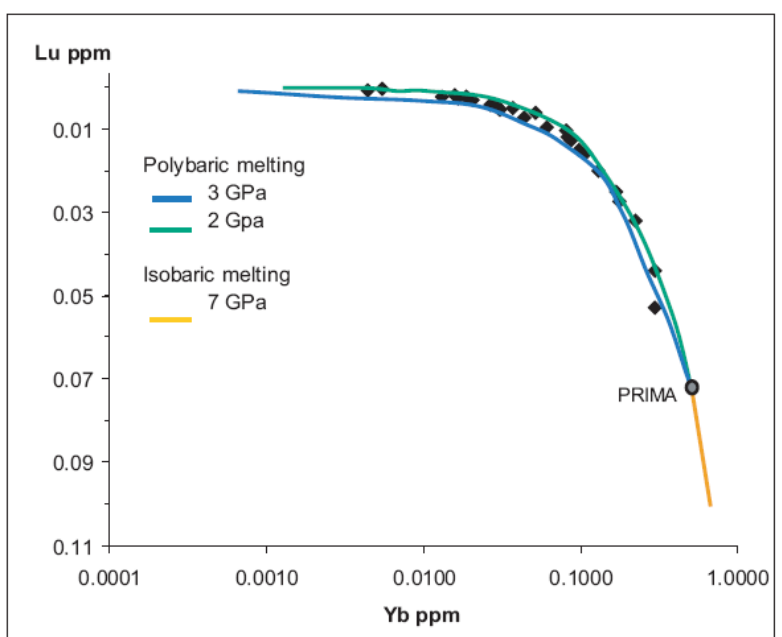

Fig.4 : Whole rock Lu versus Yb for Premier suite. Curves shows polybaric fractional melting beginning at 2 \& 3GPa and isobaric melting at 7GPa (after Pearson \& Wittig 2008).

\section{PGE and Re-Os data}

As with major and trace elements, the Premier peridotites can be split into 2 main groups on the basis of their PGE systematics (Fig.5a\&b). Group A is characterised by low $\mathrm{Pd}, \mathrm{Pt}$ concentrations and fractionation between I-PGEs (Os, Ir, Ru) and P-PGE (Pt, Pd). This group is comparable to the majority of samples derived from the Kaapvaal and other Archaean cratons (Pearson et al. 2004; Wittig et al., this volume). The other groups B-M, have relatively unfractionated PGE patterns. Groups B+M represent $60 \%$ of Premier xenoliths.

Subgroup M is very similar to group B but records greater sulphide contents and higher Pd and Re, most likely due to metasomatism.

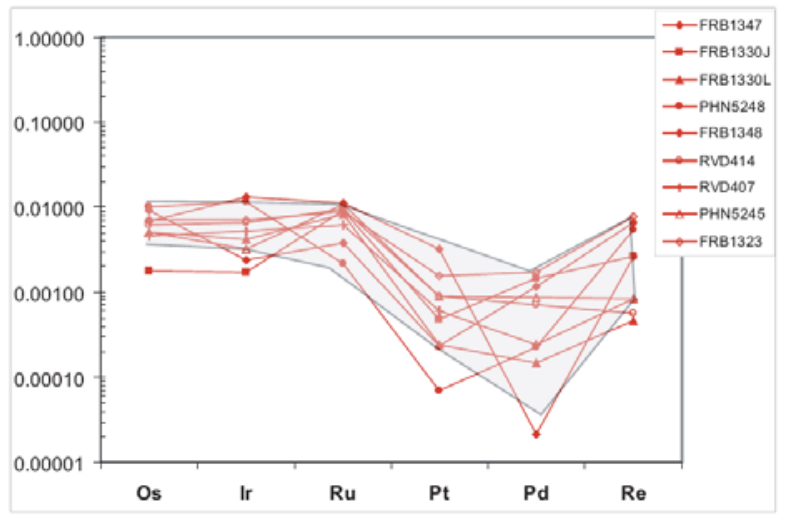

Fig.5a Whole rock chondrite normalised PGE patterns for Group A Premier peridotites. Chondrites values from McDonough and Sun, 1995. Kaapvaal grey field from Lesotho peridotites (Pearson et al., 2004). 


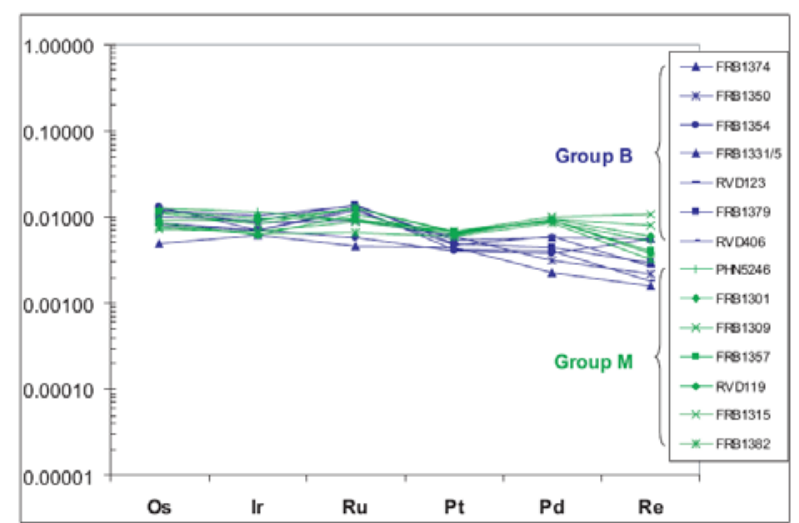

Fig.5a Same as 5 a for Group B-M Premier peridotites.

Re depletion ages are presented for Premier and a compilation of Kaapvaal samples in Fig. 6. The Premier xenoliths define two age populations. One yields Archaean ages between 2.5 and 3.4Ga while the second clusters at $2.1 \mathrm{Ga}$, the age of the Bushveld event.

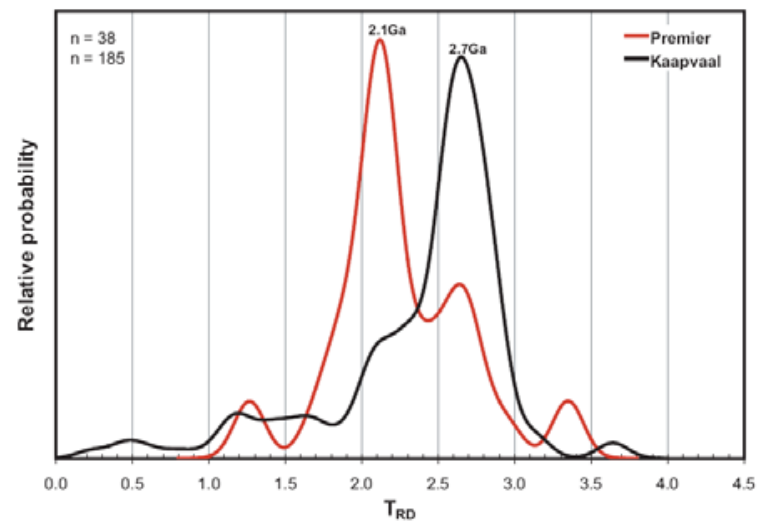

Fig.6 $T_{R D}$ age distribution for Premier samples (in red) and Kaapvaal peridotites (in black, compilation from Pearson \& Wittig, 2008). $T_{\mathrm{RD}}$ are calculated using the initial ratio corrected to the age of eruption which is 1180Ma for Premier.

These data establish that the SCLM sampled by the Premier kimberlite is of mixed origin. Some peridotitic lithosphere remains from the original generation of the Kaapvaal craton in the Archean, likely associated with suduction (Simon et al. 2007; Pearson \& Wittig, 2008). The majority of the lithosphere sampled by the kimberlite appears to have formed in association with the Bushveld Province magmatism.

The clustering and homogeneity of $\mathrm{T}_{\mathrm{RD}}$ ages from the fertile group around 2.05Ga is likely a result of new melt depletion than from the addition of metasomatic sulphides. This is confirmed by differences in major elements and mineral chemistry.

A large combined P-T and Os isotope dataset allow us to examine the variation of SCLM age with depth (Fig 7). Os model ages are variable for spinel facies and for the deepest samples which have $\mathrm{P}>6 \mathrm{GPa}$ and $\mathrm{T}>1300^{\circ} \mathrm{C} \quad\left(\mathrm{T}_{\mathrm{RD}} 3.3\right.$ and $\left.1.2 \mathrm{Ga}\right)$. In contrast, low temperature garnet peridotites and spinel-garnet facies only have $\mathrm{T}_{\mathrm{RD}}$ ages around $2.1 \mathrm{Ga}$.

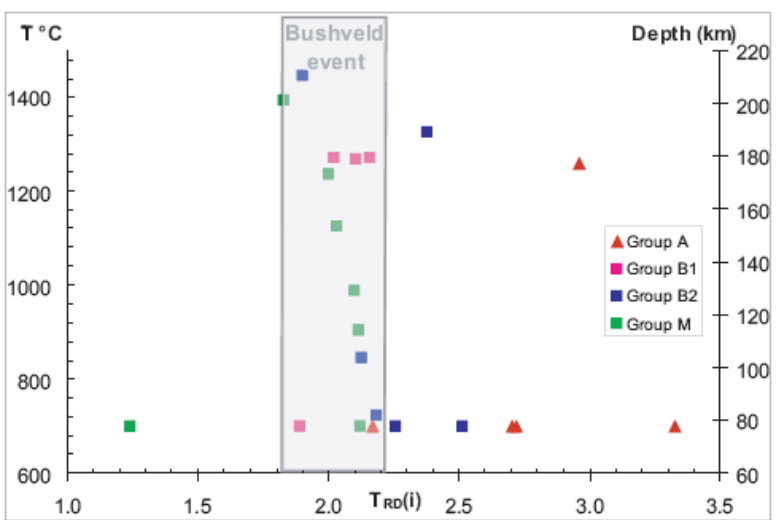

Fig.7 Re depletion ages $\left(\mathrm{T}_{\mathrm{RD}}\right)$ versus temperature of equilibration. Temperatures and pressures were calculated using standard geothermobarometry methods. Combined P-T calculations are not possible for spinel lithologies hence P-T was arbitrarly fixed at $700^{\circ} \mathrm{C}$ and 2GPa.

Premier peridotites clearly record the same Archaean history as the rest of Kaapvaal with high degrees of melting in shallow environment. However, the main suite is dominated by SCLM formation at 2Ga, associated with the Bushveld magmatic event that has caused replacement of part of the existing lithospheric mantle.

\section{References}

Bernstein et al., 2006. Consistent olivine \#Mg in cratonic mantle reflects Archaean mantle melting to the exhaustion of orthopyroxene. Geology, 35, 459-462.

Danchin, 1979. Mineral and bulk chemistry of garnet lherzolite and garnet harzburgite xenoliths from the Premier mine, South Africa. Proceedings of the $2^{\text {th }}$ kimberlite conference, volume 2, 104-126.

Herzberg, C., 2004. Geodynamic information in peridotite petrology. Journal of Petrology, 45, 2507-2530.

James, D.E., Boyd, F.R., et al., 2004. Xenoliths constraints on seismic velocities in the upper mantle beneath southern Africa. Geophysics Geochemistry, Geophysics, and Geosystems, 5, 1-32.

Kelemen, P.B., Hart, S.R. et al., 1998. Silica enrichment in the continental upper mantle via melt/rock reaction. Earth and Planetary Science Letters, 164 (1-2), 387406.

Lee, C.T., et al, 2006. Geochemical/petrologic constraints on the origin of cratonic mantle. American Geophysical Union Monograph, 89-114.

McDonough and Sun, 1995. The composition of the Earth. Chemical Geology, 120, 223-253.

Pearson, D.G. and Wittig, N, 2008. Formation of Archaean continental lithosphere and its diamonds: the root of the problem, Journal of the Geological Society, London, in press.

Pearson et al., 2004. Re-Os isotope systematics and platinum group element fractionation during mantle melt extraction: a study of massif and xenolith peridotite suites. Chemical Geology, 208, 29- 59.

Simon, N., et al, 2007. The origin and evolution of the Kaapvaal cratonic lithospheric mantle. Journal of Petrology, 48, 589-625.

Wittig, N., et al. (2008). Evolution of the mantle root beneath the North Atlantic Craton. Extended Abstracts 9th International Kimberlite Conference. 